UDC 539.3

DOI: $10.32326 / 1814-9146-2020-82-1-100-106$

\title{
EXPLICIT FORMULA FOR DEPTH OF PENETRATION OF CONE-NOSED IMPACTOR INTO ANISOTROPIC SHIELDS
}

\author{
Dubinsky A.V.
}

\author{
Ben-Gurion University of the Negev, Beer-Sheva, Israel \\ dubin@bgu.ac.il
}

Received by the Editor 2019/12/20

The field of application of Functionally Graded Materialsis steadily expanding, which stimulates research in the relevant areas. In relation to penetration mechanics, these are primarily experimental studies of multilayer barriers consisting of plates "in contact" with various mechanical properties. Despite intensive research, explicit formulas for integral penetration characteristics (penetration depth and ballistic limit) cannot be obtained, except for the case when sequential penetration of layers (barriers with large gaps between layers).

In this article, explicit formulas for the depth of penetration into an semi-infinite shield and for the ballistic limit velocity applying penetration into a shield of a finite thickness are derived assuming that the hardness of the barrier material varies continuously depending on barrier depth. The theoretical analysis is based on a model that represents the normal stress at points on the surface of the penetrating body that are in contact with the barrier as a quadratic function of the normal component of local impactor velocity with a zero linear term (the Vitman-Stepanov model). Difference of the dynamic hardness in different points of impactor-barrier contact is taken into account. It is also assumed that the nose of the striker has the form of a straight circular cone and the initial stage of penetration when the striker is not completely immersed in the barrier is ignored.

Keywords: impactor, shield, barrier, penetration, depth, anisotropy.

\section{Introduction}

The field of application of Functionally Graded Materialsis steadily expanding, which stimulates research in the relevant areas [1-4]. In relation to penetration mechanics, these are primarily experimental studies of multilayer barriers consisting of plates "in contact" with various mechanical properties, as evidenced by reviews [5-6] and review sections of monographs $[7,8]$. The theoretical analysis is based mainly on a model that represents the normal stress at points on the surface of the penetrating body that are in contact with the barrier as a quadratic function of the local normal velocity component with a zero linear term (in Russian-language publications, it is known as the Vitman - Stepanov model [9]). Usually additional simplifications are also accepted, in particular, it is assumed that the nose of the striker has the form of a straight circular cone, the specifics of the initial and final stages of penetration are ignored, when the striker is not completely immersed in the barrier, and others. Despite intensive research [10-20], explicit formulas for integral 
penetration characteristics (penetration depth and ballistic limit) cannot be obtained, except for the case when sequential penetration of layers (barriers with large gaps between layers) is actually assumed $[7,10]$.

This article is close to the work [20] on the approach to the problem. However, unlike [20], impactors that have a conical shape of the nose are considered, another approximation of the dependence of hardness on depth is used and difference of the dynamic hardness in different points of impactor-barrier contact is taken into account. This results in an explicit formula for the penetration depth with continuously varying hardness of the shield. The description of the interaction of the barrier with the striker is based on the Vitman-Stepanov model; the effects associated with incomplete immersion of the striker in the barrier at the initial stage are not taken into account .

\section{Mathematical model and statement of the problem}

Consider high speed normal penetration of a rigid, sharp (pointed) body of revolution into a shield with hardness, depending on the depth of the semi-infinite shield. It is assumed that the interaction between the projectile and the shield is described by the following two-term model what is known as the Vitman - Stepanov model [9]:

$$
d \mathbf{F}=\left[\gamma v_{n}^{2}+Y\right] \mathbf{n}^{0} d S,
$$

where $\gamma$ is density of the shield's material; $Y$ is a parameter that determines mechanical properties of the material (dynamic hardness); $d \mathbf{F}$ is the force acting on the lateral surface element $d S$ of a projectile that is in contact with the plate (barrier), $\mathbf{n}^{0}$ and $v_{n}$ are the inner normal unit vector and normal component of the instantaneous velocity of the projectile $\mathbf{v}$ at a given location on the projectile surface, correspondingly.

The resultant force acting on the projectile at each instant of time is determined by integrating $d \mathbf{F}$ over the lateral surface of the projectile-barrier contact at the same instant, $S_{\text {lat }}$. Then formula for the drag force, $D$ is the following:

$$
D=\left(-\mathbf{v}^{0}\right) \iint_{S_{\text {lat }}} d \mathbf{F}=\iint_{S_{\text {lat }}}\left(-\mathbf{v}^{0}\right) d \mathbf{F},
$$

where $\mathbf{v}^{0}$ is unit vector of the velocity of the impactor.

Hereafter we use the following notations. The coordinate $h$, the instantaneous depth of penetration, is defined as the distance between the nose of the impactor and the front surface of the barrier. The cylindrical coordinates $x, \rho, \phi$ with the origin in the nose of the impactor are associated with it whereas the coordinate $x$ directs along the axis of the impactor. The equation $\rho=\Phi(x)$, where $\Phi$ is a convex function, determines the shape of the impactor's surface, $L$ is the length of the nose of the impactor which interacts with the barrier; the impactor has also the cylindrical part of the length $L_{0}$. Note that the section $x=x_{0}$ is located at the depth $h_{0}-x_{0}$ if the nose of the impactor is situated at the depth $h=h_{0}$.

Neglecting the effect associated with the partial immersion of the impactor in the barrier at the initial stage of penetration, one can obtain the following relationship for $D$ in the case of the model given by Eq. (1) [7, 8]:

$$
D(h, v)=f_{2} v^{2}+f_{0}(h)
$$

where 


$$
f_{0}(h)=2 \pi \int_{0}^{L} Y(h-x) \Phi_{x} \Phi d x, \quad f_{2}=2 \pi \gamma \int_{0}^{L} \frac{\Phi_{x}^{3} \Phi}{\Phi_{x}^{2}+1} d x, \quad \Phi_{x}=\frac{d \Phi}{d x} .
$$

Then the equation of motion of impactor with the mass $m$ is the following:

$$
\frac{m}{2} \frac{d v^{2}}{d h}+f_{2} v^{2}+f_{0}(h)=0 .
$$

Solution of this linear relative $v^{2}$ differential equation with condition $v(0)=v_{\text {imp }}$, where $v_{\text {imp }}$ is impact velocity, can be written in the form:

$$
v^{2}(h)=\frac{1}{Q(h)}\left[v_{\mathrm{imp}}^{2}-\frac{2}{m} \int_{0}^{h} f_{0}(\tilde{h}) Q(\tilde{h}) d \tilde{h}\right],
$$

where

$$
Q(h)=\exp \left(\frac{2}{m} \int_{0}^{h} f_{2} d \zeta\right)=\exp \left(\frac{2 f_{2} h}{m}\right) .
$$

Using the condition $v(H)=0$, we obtain the equation for determining the dept of penetration (DOP) $H$ :

$$
\int_{0}^{H} f_{0}(h) Q(h) d h=\frac{m}{2} v_{\mathrm{imp}}^{2} .
$$

Our goal is to obtain an explicit formula for the DOP.

\section{Solution of the problem}

For more clarity, we consider conical-nosed impactors. In this case the equation of impactor's generatrix is written as follows:

$$
\Phi(x)=\operatorname{tg} \vartheta x,
$$

where $\vartheta$ is half apex angle of the cone and

$$
f_{0}(h)=2 \pi \operatorname{tg}^{2} \vartheta \int_{0}^{L} Y(h-x) x d x, \quad f_{2}=\pi \gamma \operatorname{tg}^{4} \vartheta \cos ^{2} \vartheta L^{2} .
$$

Then Eq. (8) is transformed to the form:

$$
\int_{0}^{H} d h \int_{0}^{L} d x\left[x Y(h-x) \exp \left(k_{2} h\right)\right]=k_{1} v_{\mathrm{imp}}^{2},
$$

where

$$
k_{1}=\frac{m}{2 \pi \operatorname{tg}^{2} \vartheta}, \quad k_{2}=\frac{2 \pi \gamma \operatorname{tg}^{4} \vartheta \cos ^{2} \vartheta L^{2}}{m} .
$$

Taking into account that

$$
m=\pi \gamma \operatorname{tg}^{2} \vartheta L^{3}\left(\frac{1}{3}+\bar{L}_{0}\right), \quad \bar{L}_{0}=\frac{L_{0}}{L},
$$

the expression for $k_{2}$ can be rewritten as follows: 


$$
k_{2}=\frac{2 \sin ^{2} \vartheta}{L\left(1 / 3+\bar{L}_{0}\right)} .
$$

For function $Y(z)$ that describes dynamic hardness $Y$ depending on the depth of the barrier $z$ one can select the approximation [2] with empirical coefficients $\alpha$ and $\beta$ :

$$
Y(z)=\alpha \exp (\beta z)
$$

that represent quit well the possible types of behavior of dependence $Y(z)$. Then Eq. (11) takes the form:

$$
\int_{0}^{H} \exp \left(k_{3} h\right) d h \int_{0}^{L} x \exp (-\beta x) d x=\frac{k_{1}}{\alpha} v_{\text {imp }}^{2} .
$$

Calculating integrals in Eq. (16) we obtain the equation:

$$
\frac{1}{k_{3}}\left[\exp \left(k_{3} H\right)-1\right] \frac{1-(L \beta+1) \exp (-\beta L)}{\beta^{2}}=\frac{k_{1}}{\alpha} v_{\mathrm{imp}}^{2},
$$

which implied the solution:

$$
H=\frac{1}{k_{2}+\beta} \ln \left(1+k_{3} v_{\mathrm{imp}}^{2}\right)
$$

where

$$
k_{3}=\frac{k_{4}}{k_{5}}, \quad k_{4}=\left(k_{2}+\beta\right) \beta^{2} \frac{k_{1}}{\alpha}, \quad k_{5}=1-(\beta L+1) \exp (-\beta L) .
$$

In the case of homogeneous media, $Y(z)=Y(0)=$ const, $\alpha=Y(0)=Y, \beta=0$. Since uncertainty $0 / 0$ appears in the right side of Eq. (19) when $\beta=0$, we use the L'Hospital rule. Then

$$
\frac{d k_{4} / d \beta}{d k_{5} / d \beta}=\frac{\beta\left(2 k_{2}+3 \beta\right)\left(k_{1} / Y\right)}{\beta L^{2} \exp (-\beta L)} \rightarrow \frac{2 k_{1} k_{2}}{Y L^{2}}
$$

and

$$
\frac{H}{L}=\frac{1}{k_{2} L} \ln \left(1+\frac{2 k_{1} k_{2}}{Y L^{2}} v_{\mathrm{imp}}^{2}\right)=\frac{1 / 3+\bar{L}_{0}}{2 \sin ^{2} \vartheta} \ln \left(1+\frac{2 \gamma \sin ^{2} \vartheta}{Y} v_{\mathrm{imp}}^{2}\right) .
$$

Consider penetration into a semiinfinite barrier of thickness $b$. The Army ballistic limit $v_{\mathrm{bl}}(\mathrm{BLV})$ is defined as the minimum impact velocity at which the striker reaches the back side of the barrier [21]. Then replacing in equation (18) $H$ by $b$ and $v_{\text {imp }}$ by $v_{\mathrm{bl}}$ we obtain the explicit formula for the BLV:

$$
v_{\mathrm{bl}}^{2}=\frac{1}{k_{3}}\left[\exp \left(b\left(k_{2}+\beta\right)\right)-1\right] .
$$

\section{Concluding remarks}

Further research within the framework of the developed approach is intended in the following areas: consideration of strikers with a nose in the form of pramids and nonconical bodies of revolution (including impactord with flat blunting); taking into account in the model the specificity of the initial stage of penetration with incomplete immersion of the striker in the barrier and friction between the striker and the barrier; use of other models describing the dependence of hardness on the depth of the barrier. 
1. Functionally Graded Materials in the $21^{\text {st }}$ Century: A Workshop on Trends and Forecasts. Ichikawa K. (ed.). Springer. 2001. 252 p.

2. Khan T., Zhang N., Akram A. State of the art review of functionally graded materials. In: $2^{\text {nd }}$ International Conference on Computing, Mathematics and Engineering Technologies. 2019. P. 1-9.

3. Larson R.A. A novel method for characterizing the impact response of functionally graded plates. Dissertation. 2008. Wright-Patterson Air Force Base, OH.

4. Pentaras D., Gentilini C. Mechanics of Functionally Graded Material Structures. World Scientific Publishing Co. 2015. 323 p.

5. Ben Dor G., Dubinsky A., Elperin T. New results on ballistic performance of multi layered metal shields: review. Theor. Appl Fract. Mec. 2017. No 88. P. 1-8.

6. Ben-Dor G., Dubinsky A., Elperin T. Investigation and optimization of protective properties of metal multi-layered shields: A Review. Int J. Prot. Struct. 2012. Vol. 3. No 3. P. 275-291.

7. Ben-Dor G., Dubinsky A., Elperin T. Engineering Models in High-Speed Penetration Mechanics and their Applications. A Two-Volume Set. Vol. 1. Engineering Models; Vol. 2. Applied Problems. World Scientific. 2019. 1076 p.

8. Aptukov V.N., Dubinskiy A.V., Khasanov A.R. Issledovanie i optimizatsiya zashchitnykh svoystv mnogosloynykh metallicheskikh pregrad pri vysokoskorostnom udare [Research and Optimization of Protective Properties of Multilayer Metal Barriers in High-Speed Impact]. Perm. Perm state national research university Publ. 2019. 430 p. (In Russian).

9. Vitman F.F., Stepanov V.A. Influence of Strain Rate on Resistance to Deformation of Metals at Impact Velocities of 100 to $1000 \mathrm{~m} / \mathrm{sec}$. Foreign Technology Division Wright-Patterson AFB, OH. 1964. 26 p. (AD0605234)].

10. Ben Dor G., Dubinsky A., Elperin T. Applied High-Speed Plate Penetration Dynamics. Dordrecht. Springer. 2006. 357 p.

11. Aptukov V.N., Murzakaev R.T., Fonarev A.V. Prikladnaya teoriya pronikaniya [Applied Theory of Penetration]. Moscow. Nauka Publ. 1992. 105 p. (In Russian).

12. Aptukov V.N., Khasanov A.R. Optimizatsiya parametrov sloistykh plit pri dinamicheskom pronikanii zhestkogo indentora s uchetom treniya i oslablyayushchego effekta svobodnykh poverkhnostey [Optimization of parameters of layered plates during dynamic hard indenter penetration with friction and weakining effect of free surfaces]. Vestnik Permskogo natsional'nogo issledovatelskogo politekhnicheskogo universiteta. Mekhanika [PNRPU Mechanics Bulletin]. 2014. No 2. P. 48-75 (In Russian).

13. Khasanov A.R. Optimalnoe tormozhenie zhestkogo konicheskogo udarnika sloistoy plitoy pri udare po normali s uchetom vyazkostnykh effektov [Optimal braking of a rigid conical impactor by a layered shield at normal impact with viscous effects]. Vestnik Permskogo universiteta. Matematika. Mekhanika. Informatika [Bulletin of Perm State University. Mathematics. Mechanics. Information]. 2018. No 2(41). P. 54-60 (In Russian).

14. Kanibolotskiy M.A., Urzhumtsev Yu. S. Optimalnoe proektirovanie sloistykh konstruktsiy [Optimal Design of Layered Structures]. Novosibirsk. Nauka Publ. 1989. 176 p. (In Russian).

15. Banichuk N.V., Ivanova S.Yu., Makeev E.V. Pronikanie zhestkikh udarnikov v sloistye plastiny i nekotorye zadachi globalnoy mnogotselevoy strukturnoy optimizatsii [Penetration of rigid strikers in layered plates and some problems of global multipurpose structural optimization]. Problemy prochnosti i plastichnosti [Problems of Strength and Plasticity]. 2012. Iss. 74. P. 124-133. (In Russian).

16.Banichuk N.V., Ivanova S.Yu., Makeev E.V., Turutko, A.I. Nekotorye analiticheskie i chislennye otsenki parametrov optimalnoy struktury zashchitnoy plity [Some analytical and computational estimates of parameters of optimal protective plate structure]. Problemy prochnosti i plastichnosti [Problems of Strength and Plasticity]. 2013. Iss. 75. Pt. 3. P. 206-214 (In Russian).

17. Banichuk N.V., Ivanova S. Yu., Ragnedda F., Serra M. Multiobjective approach for optimal design of layered plates against penetration of strikers. Mechanics Based Design of Structures and Machines. 2013. Vol. 41. No 2. P. 189-201.

18. Banichuk N.V., Ivanova S.Yu. Igrovoy podkhod k resheniyu zadachi optimizatsii formy 
udarnika i struktury sloistoy sredy pri vysokoskorostnom probivanii [The game approach to solution of an impactor shape and layered structure medium optimization problem for high speed perforation]. Problemy prochnosti i plastichnosti [Problems of Strength and Plasticity]. 2016. Vol. 78. No 4. P. 426-435 (In Russian).

19. Banichuk N.V., Ivanova S.Yu. Optimal Structural Design: Contact Problems and HighSpeed Penetration. Berlin. Boston. Walter de Gruyter GmbH. 2017. 207 p.

20. Banichuk N.V., Otgonbayar S. O dvizhenii osesimmetrichnogo udarnika v sredakh s lineyno izmenyayushchimisya prochnostnymi kharakteristikami [On axisymmetric impactor moving in media with linearly changed strength characteristics]. Problemy prochnosti i plastichnosti [Problems of Strength and Plasticity]. 2017. Vol. 79. No 4. P. 484-491 (In Russian).

21. Backman M., Goldsmith W. The mechanics of penetration of projectiles into targets. Int J. Eng. Sci. 1978. Vol. 16. No 1. P. 1-99.

\section{Список литературь}

1. Functionally Graded Materials in the $21^{\text {st }}$ Century: A Workshop on Trends and Forecasts. Ichikawa K. (ed.). Springer, 2001. 252 p.

2. Khan T., Zhang N., Akram A. State of the art review of functionally graded materials. In: $2^{\text {nd }}$ International Conference on Computing, Mathematics and Engineering Technologies. 2019. P. 1-9.

3. Larson R.A. A novel method for characterizing the impact response of functionally graded plates. Dissertation. 2008. Wright-Patterson Air Force Base, OH.

4. Pentaras D., Gentilini C. Mechanics of Functionally Graded Material Structures. World Scientific Publishing Co, 2015. 323 p.

5. Ben Dor G., Dubinsky A., Elperin T. New results on ballistic performance of multi layered metal shields: review. Theoretical and Applied Fracture Mechanics. 2017. No 88. P. 1-8.

6. Ben-Dor G., Dubinsky A., Elperin T. Investigation and optimization of protective properties of metal multi-layered shields: A Review. International Journal of Protective Structures. 2012. Vol. 3. No 3. P. 275-291.

7. Ben-Dor G., Dubinsky A., Elperin T. Engineering Models in High-Speed Penetration Mechanics and their Applications. A Two-Volume Set. Vol. 1. Engineering Models; Vol. 2. Applied Problems. World Scientific, 2019. 1076 p.

8. Аптуков В.Н., Дубинский А.В., Хасанов А.Р. Исследование и оптимизация защитных свойств многослойных металлических преград при высокоскоростном ударе. Пермь: Перм. гос. нац. исслед. ун-т, 2019. 430 с.

9. Витман Ф.Ф., Степанов В.А. Влияние скорости деформирования на сопротивление деформированию металлов при скоростях удара 100-1000 м/с. В кн.: Некоторые проблемы прочности твердого тела. АН СССР. 1959. С. 207-221.

10. Ben Dor G., Dubinsky A., Elperin T. Applied High-Speed Plate Penetration Dynamics. Dordrecht: Springer, 2006. 357 p.

11. Аптуков В.Н., Мурзакаев Р.Т., Фонарев А.В. Прикладная теория проникания. М.: Наука, 1992. 105 с.

12. Аптуков В.Н., Хасанов А.Р. Оптимизация параметров слоистых плит при динамическом проникании жесткого индентора с учетом трения и ослабляющего эффекта свободных поверхностей. Вестник Пермского национального исследовательского политехнического университета. Механика. 2014. №2. С. 48-75.

13. Хасанов А.Р. Оптимальное торможение жесткого конического ударника слоистой плитой при ударе по нормали с учетом вязкостных эффектов. Вестник Пермского университета. Математика. Механика. Информатика. 2018. Вып. 2(41). С. 54-60.

14. Каниболотский М.А., Уржумцев Ю. С. Оптимальное проектирование слоистых конструкиий. Новосибирск: Наука СО, 1989. 176 с.

15. Баничук Н.В., Иванова С.Ю., Макеев Е.В. Проникание жестких ударников в слоистые пластины и некоторые задачи глобальной многоцелевой структурной оптимизации. Проблемы прочности и пластичности. 2012. Вып. 74. С. 124-133.

16. Баничук Н.В., Иванова С.Ю., Макеев Е.В., Турутько, А.И. Некоторые аналитические 
и численные оценки параметров оптимальной структуры защитной плиты. Проблемы прочности и пластичности. 2013. Вып. 75. Ч. 3. С. 206-214.

17. Banichuk N.V., Ivanova S.Yu., Ragnedda F., Serra M. Multiobjective approach for optimal design of layered plates against penetration of strikers. Mechanics Based Design of Structures and Machines. 2013. Vol. 41. No 2. P. 189-201.

18. Баничук Н.В., Иванова С.Ю. Игровой подход к решению задачи оптимизации формы ударника и структуры слоистой среды при высокоскоростном пробивании. Проблемы прочности и пластичности. 2016. Т. 78. №4. С. 426-435.

19. Баничук Н.В., Иванова С.Ю. Оптимизация. Контактные задачи и высокоскоростное проникание. М.: Физматлит, 2016. 176 с.

20. Баничук Н.В., Отгонбаяр С. О движении осесимметричного ударника в средах с линейно изменяющимися прочностными характеристиками. Проблемы прочности и пластичности. 2017. Т. 79. №4. С. 484-491.

21. Backman M., Goldsmith W. The mechanics of penetration of projectiles into targets. International Journal of Engineering Science. 1978. Vol. 16. No 1. P. 1-99.

\section{ЯВНАЯ ФОРМУЛА ДЛЯ ГЛУБИНЫ ПРОНИКАНИЯ УДАРНИКА С КОНИЧЕСКОЙ ГОЛОВНОЙ ЧАСТЬЮ В АНИЗОТРОПНУЮ ПРЕГРАДУ}

Дубинский А.B.

Университет им. Д. Бен-Гуриона в Негеве, Беэр-Шева, Израиль

Область применения анизотропных материалов неуклонно расширяется, что стимулирует исследования в соответствующих областях. Применительно к механике проникновения это прежде всего экспериментальные исследования многослойных барьеров, состоящих из пластин с различными механическими свойствами, контактирующих друг с другом. Несмотря на интенсивные исследования, явные формулы для интегральных характеристик проникания (глубина проникания и баллистический предел) получить не удается за исключением случая, когда фактически предполагается, что слои пробиваются последовательно (барьеры с большими зазорами между слоями).

B статье получены явные формулы для глубины проникания в полубесконечную преграду и для баллистической предельной скорости проникания в преграду конечной толщины в предположении, что твердость материала барьера непрерывно изменяется в зависимости от глубины преграды. Теоретический анализ основан на модели, представляющей нормальное напряжение в точках поверхности проникающего тела, контактирующих с барьером, как квадратичную функцию нормальной составляющей локальной скорости ударника с нулевым линейным членом (модель Витмана - Степанова). Учитывается разница динамической твердости в различных точках ударного или барьерного контакта. Также предполагается, что нос бойка имеет форму прямого круглого конуса и игнорируется начальная стадия проникания, когда ударник не полностью погружен в преграду.

Ключевые слова: ударник, преграда, барьер, проникание, глубина, анизотропия. 